\title{
Papaya Ringspot Virus Influences Net Gas Exchange of Papaya Leaves
}

\author{
Thomas E. Marler, Michael V. Mickelbart, and Roland Quitugua \\ College of Agriculture and Life Sciences, University of Guam, University of \\ Guam Station, Mangilao, Guam 96923
}

Additional index words. Carica papaya, chlorophyll fluorescence, $\mathrm{CO}_{2}$ assimilation, quantum yield

\begin{abstract}
Leaves of container-grown papaya (Carica papaya L.) plants were inoculated with papaya ringspot virus (PRV) to determine its influence on dark respiration and photosynthesis. Photosynthetic capacity, apparent quantum yield, ratio of variable to maximum fluorescence from dark-adapted leaves, and photosynthetic $\mathrm{CO}_{2}$-use efficiency were reduced by $\mathrm{PRV}$ infection. Internal $\mathrm{CO}_{2}$ partial pressure at ambient external $\mathrm{CO}_{2}$ was not affected, but leaf dark respiration was increased by PRV infection. These results suggest that reduced growth, yield, and fruit quality common in PRV-infected papaya plants is caused, at least partially, by reduced photosynthesis and increased respiration.
\end{abstract}

Papaya is a popular fruit crop in the tropics and subtropics. It is an important agricultural commodity in Guam, and the current market makes producing papaya profitable. Papaya production in Guam, however, is limited severely by papaya ringspot virus (PRV), partially due to an abundance of aphid vectors and PRV-infected papaya plants in natural settings (Wall, 1989). A planting is almost always infected extensively before harvest. Although plants typically are removed soon after symp-

Received for publication 28 Feb. 1992. Accepted for publication 23 Nov. 1992. We are grateful to G.C. Wall for material and informational assistance. The cost of publishing this paper was defrayed in part by the payment of page charges. Under postal regulations, this paper therefore must be hereby marked advertisement solely to indicate this fact. toms appear, it also is common for growers to leave infected plants in the hope that some of the fruit will be marketable.

PRV reduces papaya growth, fruit set, and fruit quality and causes leaf mottling and distortion (Pohronezny and Litz, 1987; Purcifull, 1972). Plant viruses, such as leaf mosaic (Decker and Tio, 1958) or leaf reduction viruses (Singh et al., 1979), reduce photosynthesis in the host plant (Agrios, 1978). The photosynthetic capacity of a papaya genotype also influences papaya fruit quality (Salazar, 1978).

The objective of this study was to determine the effects of PRV on papaya leaf physiology. These data may explain the physiological mechanism by which PRV affects papaya growth and development and improve management of PRV-infected papaya plantings.
Plant material. 'Kapoho' papaya seeds were planted in flats in early Sept. 1991 and transplanted to 2.6-liter containers on 16 Oct. 1991. Sunshine Mix 4 (Fisons Horticulture, Vancouver, Canada) was used as the container medium. The plants were fertilized with a solution of $0.68 \mathrm{~g}$ HydroSol (W.R. Grace \& Co., Fogelsville, Pa.) and $0.45 \mathrm{~g}$ calcium nitrate/liter. The solution's nutrient concentration approximated one-half strength Hoagland's solution (Hoagland and Amon, 1950). Each container received $125 \mathrm{ml}$ of solution once a week until 2 Dec. 1991, and twice a week thereafter. The plants received rainfall or irrigation to maintain $\mathrm{H}_{2} \mathrm{O}$ content at nearcontainer capacity (determined by tensiometry). All plants were grown in full sun under insect-protective lucite screening (BioQuip Products, Santa Monica, Calif.). Maximum photosynthetic photon flux (PPF) under these conditions was $\approx 1250 \mu \mathrm{mol} \cdot \mathrm{m}^{-2} \cdot \mathrm{s}^{-1}$ at the top of the plant canopy.

On 13 Nov. 1991, when $\approx 15 \mathrm{~cm}$ high, onehalf of the plants was inoculated with PRV. The inoculum was made by grinding $1 \mathrm{~g}$ of virus-infected leaf tissue with $10 \mathrm{ml}$ potassium phosphate buffer (Purcifull, 1972). Two newly expanded leaves per plant were abraded with carborundum powder and the inoculum. Two leaves of each of the control plants were abraded similarly with carborundum powder and potassium phosphate buffer. The mottling symptoms characteristic of PRV on papaya (Purcifull, 1972) were visible on the inoculated leaves in $<2$ weeks following inoculation, and vein clearing and leaf deformation were apparent on systemically infected leaves by week 3 .

Leafgas-exchange measurements. Leaf gas exchange was measured 7 to 8 weeks after 
inoculation (5-8 Jan. 1992), when characteristic PRV leaf mottling and distortion were evident on all inoculated plants. All control plants were symptomless.

A survey of gas exchange of leaves showing PRV symptoms revealed that leaf areas with various degrees of mottling but no distortion had measurable gas exchange, whereas areas with distortion had negligible net gas exchange. As a result, leaves with mottling but no distortion were chosen for study. Recently expanded leaves of the same age were used for all measurements.

Net $\mathrm{CO}_{2}$ assimilation (A) as a function of incidental PPF was determined in six plants per treatment. The measurements were made on the first four plants per treatment on 5 Jan. 1992 and the remaining two plants per treatment on 6 Jan. The plants were transferred to a laboratory the morning they were measured. Leaf gas exchange was measured using a portable photosynthesis system (model LI-6200; LI-COR, Lincoln, Neb.) with a gas analyzer (model LI-6250). One leaf on each plant was inserted into a 1-liter chamber (model LI-6200-12) fitted with inserts to enclose 10 $\mathrm{cm}^{2}$ of leaf surface. Light was supplied by three $300-W$ quartz halogen lamps suspended above a thermal-filtering 2.3-cm-deep circulating water bath. Light level was lowered between each measurement by placing nylon screening in layers over the cuvette. This procedure allowed up to nine measurements at various light levels between the light compensation point and $1115 \mu \mathrm{mol} \cdot \mathrm{m}^{-2} \cdot \mathrm{s}^{-1}$. Ambient temperature $(33.4 \pm 0.2 \mathrm{C})$ and $\mathrm{CO}_{2}$ concentration $(358 \pm 10 \mu$ bar $)$ were maintained by opening the exhaust port between each measurement. Three 10 -sec $\mathrm{CO}_{2}$ depletion periods were recorded at each light level, and appropriate software was used to calculate A. Since all leaves were saturated at $\approx 800 \mu \mathrm{mol} \cdot \mathrm{m}^{-2} \cdot \mathrm{s}^{-1}$, $\mathrm{A}$ at the highest PPF level was considered photosynthetic capacity $\left(\mathrm{A}_{\max }\right.$.
The relationship between A and external $\mathrm{CO}_{2}$ concentration was determined using six randomly chosen plants per treatment. A and $\mathrm{CO}_{2}$ were measured on the first four plants per treatment on 7 Jan. 1992 and the two remaining plants per treatment on 8 Jan.. The laboratory conditions were the same as those described previously. The chamber was positioned to obtain a PPF of $1115 \mu \mathrm{mol} \cdot \mathrm{m}^{-2} \cdot \mathrm{s}^{-1}$. The procedure described by Davis et al. (1987) was used to determine $\mathrm{A}$ at various external $\mathrm{CO}_{2}$ concentrations from the compensation point to $\approx 700 \mu$ bar $\mathrm{CO}_{2}$. Steady-state relative humidity was maintained in the closed system by monitoring and continuously adjusting a mass-flow valve that controlled the air stream passing through a magnesium perchlorate $\mathrm{H}_{2} \mathrm{O}$ scrubber. Ambient air during measurement was $35.4 \pm 0.3 \mathrm{C}$.

Dark respiration $\left(R_{d}\right)$ was measured on one leaf on each of six randomly selected plants per treatment on 5 Jan. 1992. The chamber was enclosed in black plastic to exclude light after a leaf was inserted in the cuvette. Ambient air $(29.8 \pm 0.2 \mathrm{C})$ and $\mathrm{CO}_{2}(369 \pm 4 \mu \mathrm{bar})$ were maintained in the cuvette during dark adaptation by keeping the exhaust port on the analyzer open until measurements were made. Three 10-sec $\mathrm{CO}_{2}$ efflux periods were recorded after 10 min of dark adaptation.

Chlorophyll fluorescence was measured on one leaf on each of seven randomly selected plants per treatment on 7 Jan. 1992. Fluorescence was measured at $1400 \mathrm{HR}$ with a chlorophyll fluorescence measurement system (model CF-1000; P.K. Morgan Instruments, Andover, Mass.) on the adaxial surface of each leaf. Before fluorescence was measured, 30 min of dark adaptation was provided using the system cuvettes. Induced fluorescence was measured for $60 \mathrm{sec}$ using $475-\mu \mathrm{mol} \cdot \mathrm{m}^{-2} \cdot \mathrm{s}^{-1}$ excitation light.

Data analysis. $\mathrm{R}_{\mathrm{d}}, \mathrm{A}_{\max }$, internal $\mathrm{CO}_{2}$ concentration $\left(\mathrm{C}_{\text {int }}\right)$ at $\mathrm{A}_{\max }$, and chlorophyll fluo-

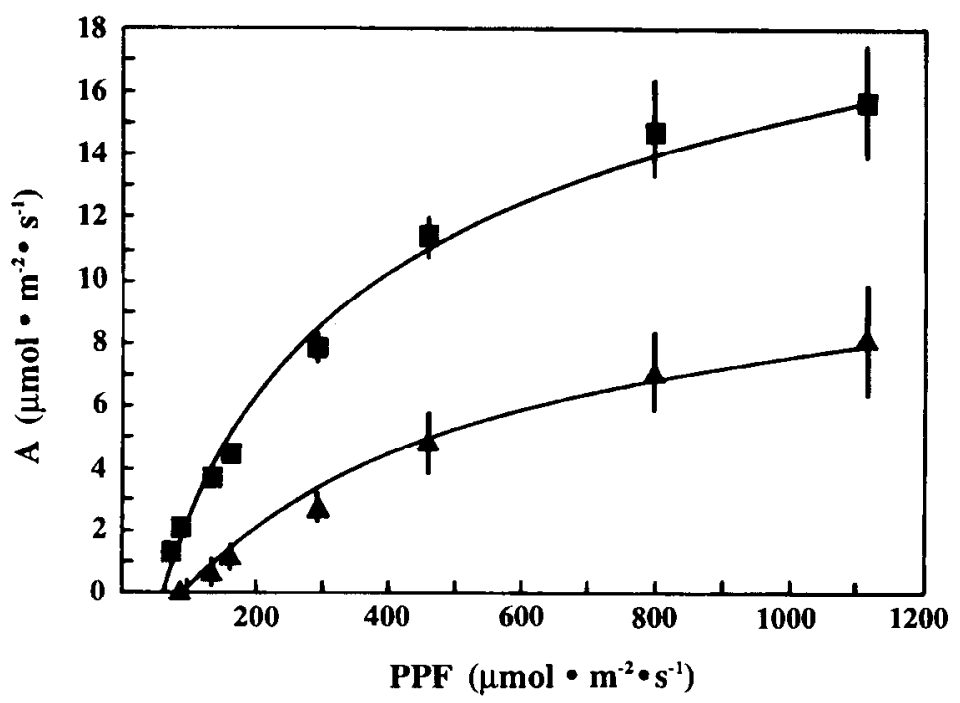

Fig. 1. Net $\mathrm{CO}_{2}$ assimilation (A) of leaves from control ( $\boldsymbol{\square}$ ) and papaya ringspot virus-infected (A) Carica papaya plants as a function of incident photosynthetic photon flux (PPF). Each point represents the mean of six replications \pm SE determined on 5-6 Jan. 1992. Equations for the response curves are $A=(-21.67)$ $+5.32 \ln$ PPF, $r^{2}=0.98$ (control); and $\mathrm{A}=(-15.77)+3.37 \ln \mathrm{PPF}, r^{2}=0.98$ (diseased); SE was smaller than symbols where no bars are visible.
Table 1. Influence of papaya ringspot virus on net $\mathrm{CO}_{2}$ assimilation at saturating light and ambient $\mathrm{CO}_{2}\left(\mathrm{~A}_{\text {max }}\right)$, internal $\mathrm{CO}_{2}$ partial pressure at $\mathrm{A}_{\max }$ $\left(\mathrm{C}_{\text {int }}\right), \mathrm{CO}_{2}$ use efficiency, apparent quantum yield $(\emptyset)$, the ratio of variable to maximal fluorescence $\left(F_{v} / F_{\text {max }}\right)$, and dark respiration $\left(R_{d}\right)$ of 'Kapoho' papaya plants. Measurements were made on systemically infected leaves, 7 to 8 weeks after inoculation $\left(n=7\right.$ for $F_{v}$ and 6 for others).

\begin{tabular}{|c|c|c|}
\hline Variable & Control & Diseased \\
\hline $\begin{array}{l}\mathrm{A}_{\max } \\
(\mu \mathrm{mol} \mathrm{CO} / \\
\left.\mathrm{m}^{2} \text { persec }\right)\end{array}$ & 15.7 & $8.9^{* * *}$ \\
\hline$\left.{ }_{(\mu \mathrm{bar}}^{\mathrm{C}_{\mathrm{int}}} \mathrm{CO}_{2}\right)$ & 273 & $267^{\mathrm{Ns}}$ \\
\hline $\begin{array}{c}\mathrm{CO}_{2} \text { use efficiency } \\
\left(\mu \mathrm{mol} \mathrm{CO}_{2} /\right. \\
\left.\mu \mathrm{bar} \mathrm{CO}_{2}\right)\end{array}$ & 0.053 & $0.030^{* *+}$ \\
\hline $\begin{array}{l}\left(\mu \mathrm{mol} \mathrm{CO} \mathrm{CO}_{2} /\right. \\
\mu \mathrm{mol} \text { photons })\end{array}$ & 0.039 & $0.016^{* * *}$ \\
\hline $\begin{array}{l}\mathrm{F}_{\mathrm{v}} / \mathrm{F}_{\max } \\
\mathrm{R}_{\mathrm{d}} \\
\quad\left(\mu \mathrm{mol} \mathrm{CO} \mathrm{CO}_{2} /\right. \\
\left.\quad \mathrm{m}^{2} \text { per sec }\right)\end{array}$ & 0.80 & $2.94^{* *}$ \\
\hline
\end{tabular}

0.01 , or 0.001 , respectively.

rescence data were subjected to analysis of variance. The response curves of $\mathrm{A}$, as influenced by light or $\mathrm{CO}_{2}$, were determined by nonlinear regression analysis. Apparent quantum yield $(\varnothing)$ was calculated using linear regression analysis as the slope of the initial part of the light response curve $\left(<150 \mu \mathrm{mol} \cdot \mathrm{m}^{-2} \cdot \mathrm{s}^{-1}\right)$. Similarly, photosynthetic $\mathrm{CO}_{2}$-use efficiency was defined as the rate of increase in $\mathrm{A}$ with increase in ambient $\mathrm{CO}_{2}$ concentration, and was calculated as the slope of the linear regression, with $\mathrm{A}$ as the dependent and $\mathrm{CO}_{2}$ concentration as the independent variable. The slopes for all replications in the control or PRVinfected groups were homogeneous based on analysis of covariance. Replications then were pooled to test if treatment differences were significant using the same test.

Papaya leaves from PRV-infected plants exhibited an $A_{\max } 57 \%$ of that of leaves from healthy plants (Fig. 1, Table 1). The light dependence of $\mathrm{A}$ in the light levels used in this study followed a logarithmic pattern (Fig. 1). Apparent $\varnothing$ of diseased leaves decreased to $41 \%$ of that of control leaves (Table 1). These results indicate that diseased plant $\mathrm{A}$ may be reduced compared to that of healthy plants, even during the initial and ending phases of each photoperiod and on severely cloudy days that are common during the rainy season of tropical environments.

PRV reduced photosynthetic $\mathrm{CO}_{2}$-use efficiency relative to that of control plants (Table 1). The change in A per unit change in external $\mathrm{CO}_{2}$ was 1.8 times greater for control plants than diseased plants. Calculations from the highest light level in the light curves revealed that the reduced $A_{\max }$, from PRV infection was not accompanied by a change in internal $\mathrm{CO}_{2}$ partial pressure (Table 1). As a result, $\mathrm{CO}_{2}$ availability as a substrate was most likely not a factor in the reduced $A_{\max }$ by PRV at ambient $\mathrm{CO}_{2}$ concentration. 
The ratio of variable to maximal fluorescence $\left(\mathrm{F}_{v} / \mathrm{F}_{\max }\right)$, taken from the fluorescence induction curves obtained from dark-adapted leaves, was lower for diseased than control papaya plants (Table 1). Fluorescence is a sensitive indicator of damage to the photosynthetic apparatus caused by environmental stress. A decline in $\mathrm{F}_{v} / \mathrm{F}_{\max }$ indicates photoinhibitory damage, and, when measured at ambient temperature, the interpretation of results is restricted to the pigments associated with photosystem II (Bolhar-Nordenkampf et al., 1989). The decline in $F_{v} / F_{\max }$ in the diseased papaya plants was due exclusively to reduced $F_{v}$ (data not shown). Environmental stress that causes thylakoid damage usually lowers the variable fluorescence yield (Krause and Weis, 1984), and reduced $F_{v}$ indicates weakened electron flow through photosystem II (Lloyd et al., 1986). This impaired photosynthetic electron transport may render PRVinfected papaya plants more susceptible to photoinhibitory damage by the high incidental PPF that is common in the tropics. Further, these data indicate that fluorescence may help in studying the influence of biotic and abiotic stresses on photosynthesis.

$\mathrm{R}_{\mathrm{d}}$ in papaya leaves was increased by PRV infection. Mean $R_{d}$ was 1.6 times higher in the diseased plants than in the healthy plants (Table 1). This increased respiratory activity, coupled with the reduced photosynthetic capacity of an individual leaf, would severely reduce the extent to which each leaf could function as a carbon source for the diseased papaya plant.

Various degrees of symptoms appeared on PRV-infected plant leaves, a characteristic typical of diseased plants in the field. Under the conditions of this study, photosynthetic capacity depended directly on the symptoms in the immediate area of gas-exchange measurements. For example, the measured $\mathrm{CO}_{2}$ flux of symptomless areas of leaf tissue on PRV-infected plants was not different from that of the control plants (data not shown). As a result, the overall canopy photosynthesis of PRV-infected papaya plants may depend on the percentage of leaves with symptoms and the severity of those symptoms.

Knowing the physiology of diseased papaya plants may help in making rational crop management decisions, since an environmental or genetic factor that influences growth can do so only by way of its effects on physiological plant processes (Kramer, 1980). These results suggest that reduced photosynthesis and increased respiration, combined with reduced leaf area, may allow PRV to reduce growth, yield, and fruit quality of infected papaya plants. Wind, drought, and edaphic conditions in heavy soils during the rainy season commonly reduce papaya productivity in Guam and other tropical regions. Producers who choose to continue to grow rather than rogue PRV-infected papaya plants should try to reduce these and other environmental stresses that may further decrease photosynthesis.

\section{Literature Cited}

Agrios, G.N. 1978. Plant pathology. 2nd ed. Academic, London.

Bolhar-Nordenkampf, H.R., S.P. Long, N.R. Baker, G. Oquist, U. Schreiber, and E.G. Lechner. 1989. Chlorophyll fluorescence as a probe of the photosynthetic competence of leaves in the field: A review of current instrumentation. Functional Ecol. 3:497-514.

Davis, J.E., T.J. Arkebauer, J.M. Norman, and J.R. Brandle. 1987. Rapid field measurement of the assimilation rate versus internal $\mathrm{CO}_{2}$ concentration relationship in green ash (Fraxinus pennsylvanica Marsh.): The influence of light intensity. Tree Physiol. 3:387-392.

Decker, J.P. and M.A. Tio. 1958. Photosynthesis of papaya as affected by leaf mosaic. J. Agr. Univ. Puerto Rico 42(3): 145-150.

Hoagland, D.R. and D.I. Amon. 1950. The water culture method for growing plants without soil. Calif. Agr. Expt. Sta. Circ. 347.

Kramer, P.J. 1980. Drought, stress, and the origin of adaptations, p. 7-20. In: N.C. Turner and P.J. Kramer (eds.). Adaptation of plants to water and high temperature stress. Wiley, New York.

Krause, G.H. and E. Weis. 1984. Chlorophyll fluorescence as a tool in plant physiology. II. Interpretation of fluorescence signals. Photosyn. Res. 5:139-157.

Lloyd, J., P. Kriedemann, L. Prior, and A. Grieve. 1986. Citrus leaf fluorescence: Water and salt effects. Acta Hort. 175:333-337.

Pohronezny, K. and R.E. Litz. 1987. Some common diseases of papaya in Florida. Florida Coop. Ext. Serv. Plant Pathol. Fact Sheet. p. 35.

Purcifull, D.E. 1972. Papaya ringspot virus. C.M.I./ A.A.B. Descriptions of plant viruses 84

Salazar, R. 1978. Determination of photosynthesis in commercial varieties of papaw (Carica papaya L.) and its possible relationship with the production and quality of the fruits. Revista ICA, Bogota 13(2):291-295.

Singh, R., R. Gangulee, and J. Roychowdhury. 1979. Photosynthetic production and hill reaction in healthy and virus infected papaya leaves. Natl. Acad. Sci. Lett. 2(1):3-4.

Wall, G.C. 1989. Papaya ringspot virus. Land Grant Inst. of the Pacific, Agr. Pests of the Pacific Ser. 